\title{
Effects of Sale of Non-Performing Loans to Asset Management Companies on Stock Performance of Banks
}

\author{
Asst. Prof. Dr. S1tkı Sönmezer (Beykent University, Turkey)
}

\begin{abstract}
Asset management Companies, starting from 2006, have a critical role in the banking sector of Turkey in terms of liquidating Non-performing loans into cash. Sale of bad debts enable banks to transfer receivables to asset management firms at a substantial discount and obtain liquidity so that they have more robust financials and their ability to focus on their core businesses which may increase productivity. The objective of this study is to determine the immediate impact of the announcement of recent sales on stock prices of banks. This study provides evidence that 22 statistically significant positive announcements versus 21 negative announcements out of 69 deals broken down by bank. Results indicate that particular deals are overpriced resulting in stock price increases and some are underpriced resulting in losses in the market. It can be inferred that information regarding with the structure and asset quality of deals are accessible.
\end{abstract}

\section{Introduction}

Asset management Companies (AMC) buy non-performing loans (NPL) from banks with a tender offer at a substantial discount and then they try to collect as much as they can via contacting customers to convince them to pay back loans and negotiate with them by pressuring them with laws to be enforced. Typically, they buy loans at $12.39 \%$, on average in our sample period, of the face value in Turkey which enables them to negotiate much better with customers than bank lawyers. Bank lawyers' drawback is that they don't have a benchmark rate to base the negotiations and it is hard for banks to authorize a lawyer to settle deals and reach an optimum solution. Selling loans to asset management firms enables them to bundle high quality debts with lower quality debts and get rid of the bad debts and also to write off the losses which brings tax advantage. They also save collection efforts and they may reduce costs in terms of employment, intelligence and suing fees that doesn't lead to collection.

This study aims to shed light to an additional effect of these firms; impact on share prices of the particular bank upon an announcement of a sold deal. When an announcement is made and there is a consequent price increase, this study assumes the sale as a positive sale on behalf of the bank from the presumption that market knows how to price the best. A decline in the stock market upon an announcement may be inferred as a negative sale indicating an inefficient sale by that particular bank.

This study has a unique data set of Turkish Vulture Market and it is the first study up to our knowledge in this realm. The constraint of this study is that it is limited with Turkish market as other countries' data set couldn't be reached.

Even though asset management firms have started their operations in the recent decade, their profitability has increased attention and People's Republican Party (CHP) has announced to eliminate them in their party program in 2015 elections. However, the advantages of these firms are clear as well as disadvantages. The assessment of the tradeoff is important.

\section{Non-Performing Loans}

Louzis, Vouldis and Metaxas (2012) have classified the determinants of NPLs in three classes. Mainly macroeconomic factors, debt and bank specific factors determine NPLs. Regarding with bank specific factors there are numerous hypothesis widely tested in the literature and relevant ones are listed here below:

Bad Management Hypothesis - bad management arising from collateral appraisals, investigating and monitoring borrowers and inability to score the credibility of the borrowers may be led by low cost efficiency which is directly proportional with increases in NPLs in the future. Berger and DeYoung (1997), Podpiera and Weili (2008) and Louzis et al, (2012) provide evidence supporting Bad Management Hypothesis. Bad management may be due to sales and time pressures to meet targets and NPLs may be inevitable the outcomes.

Skimping Hypothesis - less effort given to seek higher loan quality affects the decrease in costs and amount of NPLs positively. The tradeoff has not been supported by Louzis et al, 2012).

Moral hazard Hypothesis - Bank managers increase the riskiness of their loan portfolio on the owners' expense which leads to increases in NPLs. Berger and DeYoung (1997) and Louzis Et al, (2012) provide conflicting empirical evidences regarding with the hypotheses. Louzis et al,

Diversification Hypothesis - There is a negative relationship between diversification and NPLs. Credit risk decreases as diversification increase therefore NPLs, by intuition, shall decrease. Salas and Saurina (2002) use bank size instead of diversification opportunities and have found a negative relationship. 
Too Big to Fail Hypothesis - Bank managers may consider themselves too big to fail and assume the government will save them in case of financial crises. This presumption may lead to excess risk taking and have a positive impact on the increasing NPLs. Louzis et al, (2012) have found no significant relationship regarding with the hypothesis at the consumer group but they have provided empirical evidence at the business and mortgage sub-groups.

Tight Control Hypothesis - NPLs may be negatively related with ownership concentration. When the concentration is high, loans can be closely monitored as the controlling party is assumed to be more risk averse.

Reinhart and Rogoff (2010) claim that it is possible to deduce a banking crisis by examining NPLs. Determinants of NPLs are widely analyzed and there are even more hypotheses that have been analyzed but that is beyond the scope of this study.

Table 1 is presented to shed light to the legal grounds of NPLs in Turkish Jurisdiction. Once an NPL is considered as Group 3, Group 4 or Group 5, they are eligible for sale to AMCs.

\begin{tabular}{|l|l|}
\hline 1. Group & Standard loans and other receivables \\
\hline 2. Group & Closely Monitored loans and other receivables \\
\hline 3. Group & Low collection possibility loans and other receivables \\
\hline 4. Group & Bad debts and other receivables \\
\hline 5. Group & Loss equivalent loans and other receivables \\
\hline
\end{tabular}

Table 1. Classification of Non-Performing Loans in Turkish Legislation

\section{Asset Management Companies}

Asset Management Companies are one of the structural methods that banks use in restructuring their financials by solving their Non-performing Loans (NPL). This method enables banks to transfer NPLs to specialists in asset management and collection rather than finding solutions within the bank (Ersoy, 2007). These sales can either be a direct sale or in a form of revenue sharing. The former one is the more favored method in Turkey.

\begin{tabular}{|c|c|}
\hline Company & Year of Foundation \\
\hline Bebek Varlık Yönetimi A.Ş. & 2003 \\
\hline Girişim Varlık Yönetimi A.Ş. & 2005 \\
\hline RCT Varlık Yönetim A.Ş. & 2005 \\
\hline Anadolu Varlık Yönetim A.Ş. & 2006 \\
\hline LBT Varlık Yönetim A.Ş. & 2008 \\
\hline İstanbul Varlık Yönetimi A.Ş. & 2009 \\
\hline Efes Varlık Yönetim A.Ş. & 2010 \\
\hline Final Varlık Yönetim A.Ş. & 2011 \\
\hline Vera Varlık Yönetim A.Ş. & 2013 \\
\hline Turkasset Varlık Yönetim A.Ş. & 2013 \\
\hline Sümer Varlık Yönetim A.Ş. & 2015 \\
\hline Güven Varlık Yönetim A.Ş. & 2015 \\
\hline
\end{tabular}

Table 2. Asset Management Companies in Turkey Source: BDDK

Asset management companies are relatively young in Turkey as shown in Table 2. These companies are exempt from all taxes within the first five years since inception by law. The most recent companies may be founded to circumvent these regulations.

\begin{tabular}{|c|c|c|c|}
\hline Year & $\begin{array}{c}\text { Portfolio } \\
\text { (Million TL) }\end{array}$ & Sale Price (Million TL) & $\%$ \\
\hline 2010 & 2,139 & 246 & 11,5 \\
\hline 2011 & 2,656 & 198 & 7,45 \\
\hline 2012 & 2,527 & 359 & 14,2 \\
\hline 2013 & 2,570 & 370 & 14,4 \\
\hline 2014 & 4,305 & 586 & 13,61 \\
\hline Total & 14,197 & 1,759 & 12,39 \\
\hline
\end{tabular}

Table 3. Sales of Portfolio of Non-performing Loans by Banks between 2010-2014 Source: BDDK 
Table 3 indicates that the interest in asset sales have increased slightly as AMCs have increased their bids on average. It may be reasonable to assume shrinking profits margins for AMCs or market may be saturating. Sharp increase in 2014 may arise from increased awareness of banks about advantages of these NPL sales. Herding may even be the reason of this substantial increase.

\subsection{Advantages of Asset Management Companies}

Asset management companies provide numerous advantages to the banking system. Some advantages are vital and some are handy, this study aims to add another effects of these sales to the banking sector. Some of the advantages of these sales are addressed here below;

It can be argued that they help restructuring of the financial system in a way that when financial institutions sell out their bad debts, they obtain robustness, liquidity and trust. Moreover, written losses may bring credit discipline for further deals. Banks transfer risks to AMCs.

These firms also provide rapid solutions to liquidation sales, they provide high returns in liquidation process of bad debts, they also help asset prices to normalize; book value of debts and market value of them differs significantly which may mislead investors, creditors and stakeholders.

Economies of scale and economies of scope may be achieved when deals are pooled and sold to an entity. Increase in financial leverage and improved management conditions do also favor these sales (Selimler, 2006).

\subsection{Disadvantages of Asset Management Companies}

Banks generally have more accurate information about customers and transfer of loans may result in loss of information. AMCs may obtain information at a cost or may not even get the necessary information (Mesutoglu, 2001) as AMCs lack the essential information about the collateral and customer's ability and willingness, they have a tendency to underprice deals which results as a loss in the banking industry. The profits made by AMCs are the loss of the society. In other words, if the bank could sell the deal to the borrower at the sale price of the $\mathrm{AMC}$, borrowers would save the profit amount of the AMC. This inefficiency raise concerns about these deals.

Similarly, when AMCs obtain underpriced deals, they are inclined to sell the loans at below optimum prices as their profit margins are excessive. The profit margin of the AMC could be transferred to bank. Some banks elect to open up their own subsidiary AMCs to keep the profits but they don't necessarily sell to their subsidiaries but pursue best price in the market.

Either public or private these sales may not be detached from political pressures. Especially, in the former one, the system may convert into a loss transfer mechanism. Regulations may not be adequate and it may be hard to closely monitor side deals. When banks sell the loans on their own, moral hazard may also be lower.

\section{Data and Methodology}

Data is consisted of 97 deals sold by 11 banks to various AMCs in the period of 2010-2014. However, some of them are sold on the same date with different structures however, their price impact cannot be differentiated therefore, 69 announcement dates are present in the sample. This study utilizes VAR analysis by finding excess returns of each banks under study over market index returns. The study aims to provide evidence by obtaining results indicating that announcement day returns are statistically different than average returns.

\section{Findings}

Deals and their impact on prices are analyzed for each bank. Generally, it is evident that there is a price impact of announced deals but how the sale is perceived determines the direction of prices. Sales amount, portfolio amount, the structure of the portfolio, and the buyer may play a role in the price shifts but the announcement date effect is obvious; out of 69 deals 22 positive, 21 negative and 26 inconclusive 1-day statistically significant stock returns are found. The results are presented for each bank in order to present NPL management styles, pricing ability and market capitalization of these banks.

AKBANK have enjoyed four substantial increases and have had one significant negative return out of 6 deals. Interestingly, the price of the stock had not moved significantly when the bank had sold the best deal percentage wise, $88.57 \%$, which is highly over the industry averages. This may be due to the structure of that particular deal, market may have the information about how well the deal is collateralized; there should be an increase otherwise. This may indicate that market has access to detailed information about NPL sales. 


\begin{tabular}{|c|c|c|c|c|c|c|c|}
\hline BANK & Portfolio Amount & Sales Price & Ratio & Date & Structure & $\begin{array}{l}\text { 1-day return } \\
\text { of stock }\end{array}$ & $\begin{array}{l}\text { 1-day } \\
\text { return of } \\
\text { BIST } 100\end{array}$ \\
\hline AKBANK & 250.546 .000 & 41.000 .000 & $16,36 \%$ & 23.12 .2014 & $\begin{array}{l}\text { Cr. Cards } \\
\text { Consumer }\end{array}$ & $-0,0159 * * *$ & 0,0017 \\
\hline AKBANK & 248.540 .000 & 40.300 .000 & $16,21 \%$ & 23.12 .2014 & Consumer & & \\
\hline AKBANK & 252.153 .221 & 44.000 .000 & $17,45 \%$ & 14.03 .2014 & Consumer & $0,0034 * *$ & $-0,0094$ \\
\hline AKBANK & 250.465 .000 & 58.300 .000 & $23,28 \%$ & 14.05 .2013 & Corporate & $0,0180 * *$ & 0,0099 \\
\hline AKBANK & 1.242 .000 & 1.100 .000 & $88,57 \%$ & 03.05 .2013 & Consumer & 0,0102 & 0,0184 \\
\hline AKBANK & 499.183 .576 & 85.000 .000 & $17,03 \%$ & 14.09 .2012 & $\begin{array}{l}\text { Trade } \\
\text { Consumer }\end{array}$ & $0,0112 * * *$ & 0,0024 \\
\hline AKBANK & 323.388 .221 & 38.500 .000 & $11,91 \%$ & 04.01 .2010 & $\begin{array}{l}\text { Trade SME } \\
\text { Consumer }\end{array}$ & $0,0106 * * *$ & $-0,0088$ \\
\hline
\end{tabular}

$* * * \% 1$ level of significance **\%5 level of significance *\%10 level of significance

Table 4. Announcement day effect of AKBANK (TL)

Denizbank had significant negative returns after NPL sales announcements are made, 5 out of 9 deals has brought daily losses whereas in one deal excess return over the market had significantly helped her investors by storing stocks value when the market was substantially down. These results indicate that market believes the portfolios should be sold to a higher price.

\begin{tabular}{|c|c|c|c|c|c|c|c|}
\hline BANK & $\begin{array}{l}\text { Portfolio } \\
\text { Amount }\end{array}$ & Sales Price & Ratio & Date & Structure & $\begin{array}{l}\text { 1-day return } \\
\text { of stock }\end{array}$ & $\begin{array}{l}\text { 1-day return } \\
\text { of BIST } 100\end{array}$ \\
\hline DENIZBANK & 125.800 .000 & 19.050 .000 & $15,14 \%$ & 01.12 .2014 & SME-micro & 0,0077 & 0,0139 \\
\hline DENIZBANK & 125.800 .000 & 19.100 .000 & $15,18 \%$ & 01.12 .2014 & Consumer & & \\
\hline DENIZBANK & 88.800 .000 & 7.100 .000 & $8,00 \%$ & 01.12 .2014 & SME & & \\
\hline DENIZBANK & 51.332 .638 & 6.005 .919 & $11,70 \%$ & 12.12 .2013 & Trade & $-0,0044$ & $-0,0120$ \\
\hline DENIZBANK & 122.579 .295 & 25.104 .240 & $20,48 \%$ & 12.12 .2013 & Trade & & \\
\hline DENIZBANK & 31.417 .000 & 950.000 & $3,02 \%$ & 28.09 .2012 & $\begin{array}{l}\text { Consumer - } \\
\text { Trade }\end{array}$ & $-0,0188 * * *$ & $-0,0049$ \\
\hline DENIZBANK & 36.523 .567 & 6.250 .000 & $17,11 \%$ & 28.09 .2012 & Trade & & \\
\hline DENIZBANK & 60.788 .376 & 7.550 .000 & $12,42 \%$ & 02.07 .2012 & $\begin{array}{l}\text { Consumer } \\
\text { Trade }\end{array}$ & $0.000 * * *$ & $-0,0599$ \\
\hline DENIZBANK & 43.680 .000 & 7.000 .000 & $16,03 \%$ & 28.06 .2012 & Trade & $-0,0088^{*} *$ & 0,0007 \\
\hline DENIZBANK & 118.324 .000 & 14.950 .000 & $12,63 \%$ & 27.09 .2011 & Trade & 0,0170 & 0,0175 \\
\hline DENIZBANK & 32.979 .210 & 1.850 .000 & $5,61 \%$ & 25.03 .2011 & Trade & $-0,0132 * * *$ & 0,0232 \\
\hline DENIZBANK & 17.552 .681 & 1.600 .000 & $9,12 \%$ & 30.09 .2010 & Trade & - & $-0,0001$ \\
\hline DENIZBANK & 32.170 .000 & 3.206 .000 & $9,97 \%$ & 29.09 .2010 & Consumer & $-0,0081^{*}$ & 0,0062 \\
\hline DENIZBANK & 50.200 .000 & 4.900 .000 & $9,76 \%$ & 25.01 .2010 & Consumer & $-0,0244 * * *$ & $-0,0055$ \\
\hline
\end{tabular}

Table 5. Announcement day effect of DENIZBANK (TL)

Finansbank's announcements had two positive and two negative statistically significant impact on her stock price out of seven deals. Strikingly, the stock has enjoyed the highest return when sales to portfolio amount ratio is at $6.20 \%$. market may speculate regarding with the transaction as bank converting junk loans into cash. 


\begin{tabular}{|c|c|c|c|c|c|c|c|}
\hline BANK & $\begin{array}{l}\text { Portfolio } \\
\text { Amount }\end{array}$ & Sales Price & Ratio & Date & Structure & $\begin{array}{c}\text { 1-day return } \\
\text { of stock }\end{array}$ & $\begin{array}{c}\text { 1-day } \\
\text { return of } \\
\text { BIST } \\
100\end{array}$ \\
\hline FINANSBANK & 109.000 .000 & 22.890 .000 & $21,00 \%$ & 09.12 .2014 & & $-0,0097 * *$ & $-0,005$ \\
\hline FINANSBANK & 109.000 .000 & 21.800 .000 & $20,00 \%$ & 09.12 .2014 & & & \\
\hline FINANSBANK & 109.000 .000 & 20.710 .000 & $19,00 \%$ & 09.12 .2014 & & & \\
\hline FINANSBANK & 150.318 .753 & 4.800 .000 & $3,19 \%$ & 09.06 .2014 & & $0,0032 * * *$ & 0,0131 \\
\hline FINANSBANK & 95.281 .370 & 6.700 .000 & $7,03 \%$ & 09.06 .2014 & & & \\
\hline FINANSBANK & 37.437 .550 & 750.000 & $2,00 \%$ & 09.06 .2014 & & & \\
\hline FINANSBANK & 180.652 .909 & 33.000 .000 & $18,27 \%$ & 20.05 .2014 & & $-0,0032$ & $-0,0020$ \\
\hline FINANSBANK & 180.509 .013 & 34.600 .000 & $19,17 \%$ & 20.05 .2014 & & & \\
\hline FINANSBANK & 180.547 .743 & 35.600 .000 & $19,72 \%$ & 20.05 .2014 & & & \\
\hline FINANSBANK & 153.455 .084 & 20.000 .000 & $13,03 \%$ & 20.05 .2014 & & & \\
\hline FINANSBANK & 39.213 .252 & 4.400 .000 & $11,22 \%$ & 20.05 .2014 & & & \\
\hline FINANSBANK & 182.918 .000 & 35.000 .000 & $19,13 \%$ & 25.06 .2013 & & $0,0168^{* * *}$ & $-0,0065$ \\
\hline FINANSBANK & 182.888 .000 & 32.600 .000 & $17,83 \%$ & 14.06 .2013 & & 0,0126 & 0,0140 \\
\hline FINANSBANK & 182.909 .000 & 32.500 .000 & $17,77 \%$ & 14.06 .2013 & & & \\
\hline FINANSBANK & 95.900 .000 & 5.950 .000 & $6,20 \%$ & 29.09 .2011 & & $0,0311 * * *$ & 0,0142 \\
\hline FINANSBANK & 187.800 .000 & 11.500 .000 & $6,12 \%$ & 25.08 .2011 & Trade & 0,0028 & 0,0093 \\
\hline
\end{tabular}

Table 6. Announcement day effect of FINANSBANK (TL)

Garanti Bank has inconclusive results as well. Two significant increases and two significant decrease have occurred in six deals. A massive portfolio amount was sold to its $3.40 \%$ and this write off has probably deteriorated its financials. This reality seems rapidly adjusted by the market. Tax advantage generated by a sale of 1.478.137.000 TL, which is roughly 547 million USD as of 1 July 2015; Provisions are solved etc. yet there is a price to take into account by managers.

\begin{tabular}{|c|r|r|r|r|r|c|c|}
\hline BANK & \multicolumn{1}{|c|}{$\begin{array}{c}\text { Portfolio } \\
\text { Amount }\end{array}$} & Sales Price & Ratio & Date & Structure & $\begin{array}{c}\text { 1-day return } \\
\text { of stock }\end{array}$ & $\begin{array}{c}1 \text {-day } \\
\text { return of } \\
\text { BIST } 100\end{array}$ \\
\hline GARANTI & 106.598 .905 & 18.700 .000 & $17,54 \%$ & 21.08 .2014 & & 0,0048 & 0,0031 \\
\hline GARANTI & 75.000 .000 & 12.000 .000 & $16,00 \%$ & 21.05 .2014 & & $0,0320^{* * *}$ & 0,0185 \\
\hline GARANTI & 76.806 .000 & 11.911 .000 & $15,51 \%$ & 21.05 .2014 & & & \\
\hline GARANTI & 314.200 .000 & 56.400 .000 & $17,95 \%$ & 14.06 .2013 & & $0,0548^{* * *}$ & 0,0140 \\
\hline GARANTI & 200.654 .023 & 32.600 .000 & $16,25 \%$ & 13.06 .2012 & & $-0,0062 *$ & 0,0071 \\
\hline GARANTI & 1.478 .137 .000 & 50.267 .000 & $3,40 \%$ & 07.02 .2011 & & $-0,0185^{* * *}$ & 0,0345 \\
\hline GARANTI & 51.804 .000 & 3.900 .000 & $7,53 \%$ & 01.12 .2010 & & 0,0288 & 0,0217 \\
\hline
\end{tabular}

\footnotetext{
$* * * \% 1$ level of significance **\%5 level of significance *\%10 level of significance
}

Table 7. Announcement day effect of GARANTIBANK (TL)

NPL sales have had negative impact on Isbank stock, four significant decreases and one increase out of 9 deals was the case in the period under study. The heaviest decline, $4.04 \%$, was when the portfolio is sold to $9 \%$ of its face value. 


\begin{tabular}{|c|r|r|r|r|r|r|c|}
\hline & \multicolumn{1}{|c|}{$\begin{array}{l}\text { Portfolio } \\
\text { Amount }\end{array}$} & Sales Price & Ratio & Date & Structure & $\begin{array}{c}\text { 1-day } \\
\text { 1-day return } \\
\text { of stock }\end{array}$ & $\begin{array}{c}\text { return of } \\
\text { BIST } \\
100\end{array}$ \\
\hline ISBANK & 245.000 .000 & 22.050 .000 & $9,00 \%$ & 06.11 .2014 & & $-0,0404 * * *$ & $-0,0201$ \\
\hline ISBANK & 272.517 .432 & 44.016 .816 & $16,15 \%$ & 26.05 .2014 & & 0,0210 & 0,0280 \\
\hline ISBANK & 163.865 .085 & 32.041 .368 & $19,55 \%$ & 08.10 .2013 & & $-0,0113 * * *$ & 0,0016 \\
\hline ISBANK & 285.600 .000 & 50.200 .000 & $17,58 \%$ & 29.11 .2012 & & $-0,0069$ & 0,0050 \\
\hline ISBANK & 137.328 .434 & 28.800 .000 & $20,97 \%$ & 13.06 .2012 & & 0,0049 & 0,0071 \\
\hline ISBANK & 220.149 .000 & 42.200 .000 & $19,17 \%$ & 18.11 .2011 & & $-0,0051^{* *}$ & $-0,0148$ \\
\hline ISBANK & 88.464 .000 & 13.905 .000 & $15,72 \%$ & 23.06 .2011 & & $0,0148 * * *$ & $-0,0150$ \\
\hline ISBANK & 304.097 .000 & 51.500 .000 & $16,94 \%$ & 29.12 .2010 & & $-0,0036$ & $-0,0087$ \\
\hline ISBANK & 41.900 .000 & 6.500 .000 & $15,51 \%$ & 28.12 .2010 & & $-0,0030 * * *$ & 0,0178 \\
\hline
\end{tabular}

$* * * \% 1$ level of significance $* * \% 5$ level of significance *\%10 level of significance

Table 8. Announcement day effect of ISBANK (TL)

Out of twelve deals YKB had five positive announcements and 4 negative announcements stock price wise.

\begin{tabular}{|c|c|c|c|c|c|c|c|}
\hline BANK & $\begin{array}{l}\text { Portfolio } \\
\text { Amount }\end{array}$ & Sales Price & Ratio & Date & Structure & $\begin{array}{l}\text { 1-day return } \\
\text { of stock }\end{array}$ & $\begin{array}{c}\text { 1-day } \\
\text { return of } \\
\text { BIST } \\
100\end{array}$ \\
\hline YKB & 30.561 .000 & 4.150 .000 & $13,58 \%$ & 11.12 .2014 & & $0,0020 * *$ & 0,0158 \\
\hline YKB & 30.559 .000 & 4.150 .000 & $13,58 \%$ & 11.12 .2014 & & & \\
\hline YKB & 169.833 .000 & 23.430 .000 & $13,80 \%$ & 22.09 .2014 & & $0,0089 * *$ & $-0,009$ \\
\hline YKB & 56.393 .000 & 2.500 .000 & $4,43 \%$ & 22.09 .2014 & & & \\
\hline YKB & 56.128 .000 & 2.500 .000 & $4,45 \%$ & 22.09 .2014 & & & \\
\hline YKB & 54.314 .875 & 8.230 .000 & $15,15 \%$ & 20.06 .2014 & & $-0,0108 * *$ & $-0,0061$ \\
\hline YKB & 49.490 .282 & 7.310 .000 & $14,77 \%$ & 20.06 .2014 & & & \\
\hline YKB & 11.213 .000 & 10.652 .350 & $95,00 \%$ & 11.02 .2014 & & 0,0089 & 0,0094 \\
\hline YKB & 107.704 .808 & 20.230 .000 & $18,78 \%$ & 20.12 .2013 & & $0,0052 * * *$ & $-0,0217$ \\
\hline YKB & 53.822 .012 & 9.795 .606 & $18,20 \%$ & 20.12 .2013 & & & \\
\hline YKB & 53.287 .754 & 9.698 .371 & $18,20 \%$ & 20.12 .2013 & & & \\
\hline YKB & 59.946 .600 & 11.900 .000 & $19,85 \%$ & 05.12 .2012 & & 0,0101 & 0,0150 \\
\hline YKB & 59.783 .142 & 12.105 .000 & $20,25 \%$ & 05.12 .2012 & & & \\
\hline YKB & 73.711 .000 & 15.058 .000 & $20,43 \%$ & 05.12 .2012 & & & \\
\hline YKB & 372.600 .000 & 16.000 .000 & $4,29 \%$ & 05.12 .2012 & & & \\
\hline YKB & 60.022 .000 & 11.750 .000 & $19,58 \%$ & 21.11 .2012 & & 0,0089 & 0,0028 \\
\hline YKB & 290.276 .000 & 45.800 .000 & $15,78 \%$ & 05.12 .2011 & & $0,0228^{* *}$ & 0,0139 \\
\hline YKB & 88.717 .973 & 14.375 .000 & $16,20 \%$ & 26.11 .2010 & & $-0,0375 * * *$ & $-0,0120$ \\
\hline YKB & 82.149 .445 & 10.060 .000 & $12,25 \%$ & 26.11 .2010 & & & \\
\hline YKB & 256.900 .000 & 31.604 .000 & $12,30 \%$ & 26.11 .2010 & & & \\
\hline YKB & 224.400 .000 & 18.000 .000 & $8,02 \%$ & 18.03 .2010 & & $-0,0222 * * *$ & $-0,0085$ \\
\hline YKB & 74.606 .000 & 6.450 .000 & $8,65 \%$ & 17.03 .2010 & & $0,0405^{* *}$ & 0,0266 \\
\hline YKB & 382.107 .021 & 32.435 .000 & $8,49 \%$ & 01.03 .2010 & & $0,0120 * *$ & 0,0285 \\
\hline
\end{tabular}

$* * * \% 1$ level of significance $* * \% 5$ level of significance *\%10 level of significance

Table 9. Announcement day effect of YAPI VE KREDI BANK (TL)

Other banks also had similar results as banks mentioned above; six positive and four negative announcements out of nineteen deals. Relatively smaller cap banks react differently when an information is disseminated. It's worth to note that Tekstilbank didn't had a great sale, just around $6 \%$ of the portfolio amount, but enjoyed almost a return of $6 \%$. Investors may use announcements to speculate especially in inefficient markets where depth is low. 


\begin{tabular}{|c|c|c|c|c|c|c|c|}
\hline BANK & $\begin{array}{l}\text { Portfolio } \\
\text { Amount }\end{array}$ & Sales Price & Ratio & Date & Structure & $\begin{array}{l}\text { 1-day return } \\
\text { of stock }\end{array}$ & $\begin{array}{c}\text { 1-day } \\
\text { return of } \\
\text { BIST } 100\end{array}$ \\
\hline ABANK & 91.738 .986 & 19.200 .000 & $20,93 \%$ & 25.06 .2013 & MIXED & $-0,0075$ & $-0,0065$ \\
\hline ABANK & 92.800 .000 & 18.000 .000 & $19,40 \%$ & 20.06 .2013 & MIXED & $-0,0076 * * *$ & $-0,0414$ \\
\hline ABANK & 58.433 .761 & 7.750 .000 & $13,26 \%$ & 12.12 .2012 & CONSUMER & $-0,0001$ & $-0,0060$ \\
\hline ABANK & 34.535 .000 & 1.250 .000 & $3,62 \%$ & 29.12 .2010 & CONSUMER & $0,0181 * * *$ & $-0,0087$ \\
\hline ABANK & 59.605 .000 & 11.525 .000 & $19,34 \%$ & 10.11 .2010 & $\begin{array}{c}\text { CREDIT } \\
\text { CARD }\end{array}$ & $-0,0059$ & $-0,0008$ \\
\hline ASYAB & 371.158 .000 & 600.000 & $0,16 \%$ & 24.06 .2014 & TRADE & $-0,0126 * * *$ & 0,0156 \\
\hline ASYAB & 180.800 .000 & 36.600 .000 & $20,24 \%$ & 12.05 .2014 & $\begin{array}{l}\text { CREDIT } \\
\text { CARD }\end{array}$ & $0.0^{* *}$ & 0,0101 \\
\hline ASYAB & 140.000 .000 & 8.200 .000 & $5,86 \%$ & 21.06 .2013 & CONSUMER & $-0,0222$ & $-0,0247$ \\
\hline ASYAB & 461.236 .000 & 18.100 .000 & $3,92 \%$ & 05.06 .2013 & TRADE & $-0,0225 * * *$ & 0,0077 \\
\hline ŞEKER & 172.642 .882 & 16.000 .000 & $9,27 \%$ & 24.12 .2012 & & 0,0058 & 0,0083 \\
\hline ŞEKER & 23.961 .000 & 5.050 .000 & $21,08 \%$ & 21.12 .2012 & & $-0,0057$ & $-0,0083$ \\
\hline ŞEKER & 144.228 .597 & 12.000 .000 & $8,32 \%$ & 24.03 .2011 & & $0,0120 * * *$ & $-0,0264$ \\
\hline TEB & 117.000 .000 & 13.757 .000 & $11,76 \%$ & 27.06 .2013 & & $0,0619 * * *$ & 0,0294 \\
\hline TEB & 188.700 .000 & 22.222 .222 & $11,78 \%$ & 30.11 .2012 & & 0,0054 & $-0,0021$ \\
\hline TEB & 124.050 .420 & 16.900 .000 & $13,62 \%$ & 04.04 .2012 & & $0.00^{* * *}$ & $-0,0130$ \\
\hline TEB & 75.008 .000 & 6.500 .000 & $8,67 \%$ & 28.06 .2010 & & $0,0316^{* * *}$ & 0,0118 \\
\hline TEB & 39.957 .000 & 4.125 .000 & $10,32 \%$ & 12.04 .2010 & & $-0,0078^{* *}$ & 0,0060 \\
\hline TEKST & 22.623 .250 & 1.500 .000 & $6,63 \%$ & 10.03 .2014 & & $0,0598 * * *$ & $-0,0157$ \\
\hline TEKST & 60.489 .325 & 200.000 & $0,33 \%$ & 10.03 .2014 & & & \\
\hline
\end{tabular}

Table 10. Announcement day effect of Other Banks (TL)

\section{Conclusion}

Asset management firms are relatively young institutions in emerging markets but yet their advantages and disadvantages for the market are heavily debated. Despite drawbacks, these firms provide agility, liquidity, tax advantage and robustness to the banking sector.

In the sample period, results show that there is a struggle between AMCs and banks in terms of pricing the tenders. Some deals are found to be over priced; this may arise from the increased competition in the asset management sector. Announcement of overpriced deals are welcome in the financial market.

Some deals are underpriced; AMCs may assess the deals highly risky and may refrain from bidding up. When that is the case, investors start selling stock markets as the financial ratios are affected adversely. The asset management sector itself may face the problem of obtaining deal flow in the future as banks have emptied their sack of non-performing loans of years; building up new sums may take time and mergers and acquisitions in the sector seems likely.

Currently, banks are relatively more experienced with these deals and they are more keen on pricing, bundling and detaching particular deals out of the bundle. AMCs will be more cautious in the future to avoid losses and the market is expected to shrink with mergers and acquisitions. Yet, the appetite for these firms are clear in the growing number of them within a short period of time. The need for them may be speculated but for the countries that lack the legislation for these companies.

Turkish example may help to Eurasian markets even though, they differ in terms of credit card usage, nonperforming loans, laws and legislations but they may find a similar country that has the most suitable regulations in place. AMCs may exist or not in Eurasian markets but their effects on the banking system may be of interest as their vitality may be questioned in these markets as well. Further study will aim to determine the factors affecting non-performing loan sales.

\section{References}

- Aslan, E. 2002, “Türkiye'de VYŞ Kuruluşuna İlişkin Gelişmeler”, BDDK Bankacılık Sektörünün Yeniden Yapılandırılması Programı. 
- Berger, A., DeYoung, R., 1997. "Problem loans and Cost Efficiency in Commercial Banks." Journal of Banking and Finance 21, p. 849-870

- Claudia, D., 1998, “Market-Based Policy Instruments for Systemic Bank Restructuring”, International Monetary Fund Working Paper, WP/98/113.

- Ersoy, H., 2007, "Finansal Krizlerin Çözümleme Süreçleri ve Yöntemleri (Türkiye-Kore-Meksika Deneyimlerinin Karşılaştırmalı Analizi)", Marmara Üniversitesi, Bankacılık ve Sigortacılık Enstitüsü, Bankacılık Anabilim Dalı, İstanbul

- Klingebiel, D., 2000, "The Use of Asset Management Companies In The Resolution of Banking Crisis", World Bank Policy Research Working Paper, WPS/2284,

- Louzis D. P., Vouldis A. T., Metaxas V.1., 2012 "Macroeconomic and bank-specific determinants of nonperforming loans in Greece: A comparative study of mortgage, business and consumer loan portfolios" Journal of Banking \& Finance, Vol 36, Issue 4, p. 1012-1027.

- Mesutoğlu, B., 2001, "Sorunlu Aktiflerin Varlık Yönetimi Şirketlerince Tasfiyesi - Ülke Örnekleri", Bankacılık Düzenleme ve Denetleme Kurumu, MSPD Report.

- $\quad$ Podpiera, J., Weill, L., 2008. "Bad luck or bad management? “ Emerging Banking Market Experience. Journal of Financial Stability 4, p. 135-148.

- Reinhart, C., Rogoff, K., 2010. “From Financial Crash to Debt Crisis”. NBER Working Paper 15795.

- Salas, V., Saurina, J., 2002. "Credit risk in two institutional regimes: Spanish commercial and savings banks.” Journal of Financial Services Research 22, p. 203-224.

- Selimler, H., 2006, "Türk Bankacılık Sektöründe Sorunlu Kredilerin Varlık Yönetim Şirketlerince Tasfiyesi, Seçilmiş Ülkeler ve Türkiye Uygulaması”, Marmara Üniversitesi, Bankacılık ve Sigortacılık Enstitüsü, Bankacılık Anabilim Dalı (Unpublished Phd thesis), İstanbul.

- Woo D, 2000, “Two Approaches to Resolving Nonperforming Asset During Financial Crises”, IMF Working Paper No: WP/00/33, p. 6-7 